\title{
口腔惡性腫瘍トWassermann 氏反應ニ就テ
}

\author{
東京帝國大學硻學部莮科學教室（主任 金森教授）
}

高橋 利 貞

\section{第1章 緒言}

口腔領域二發生スル惡性腫瘍特二癌腫卜徽毒 卜人關係二就イテハ病因的二從來ヨリ昰ン二論 議サレテ交獻上二數多ノ記載キ見ルガ未ダ一定 人成果キ期待シ得ザル現況デアル。余八昭和 3 年 1 月ヨリ昭和 10 年 12 月二至儿滿 8 ケ年間二
取リ扱ハレタ口腔惡性腫瘍 70 例中 Wassermann 氏反應陽性ナル 症例 16 例二就テ統計的 二觀察シテ以テ大方，御敎示テ仰ギ度イト思 ᄀ。

\section{第 2 章 統計的萑察}

第 1 表二於イテ見ラル、樣二徽毒血清反隹入陽性 ナ口胿，惡性腫痘患者數八16 例デ，徽毒二曜患或八 諎跡习認メラル、モノハ7 例デアル。ソシテ是等ノ內 感染後/經過時日/明ラカナ症例 5 例/腫瘍發生二 至ル迄，本均經過日數ハ約 25.4 年デアル。

第 1 症 例

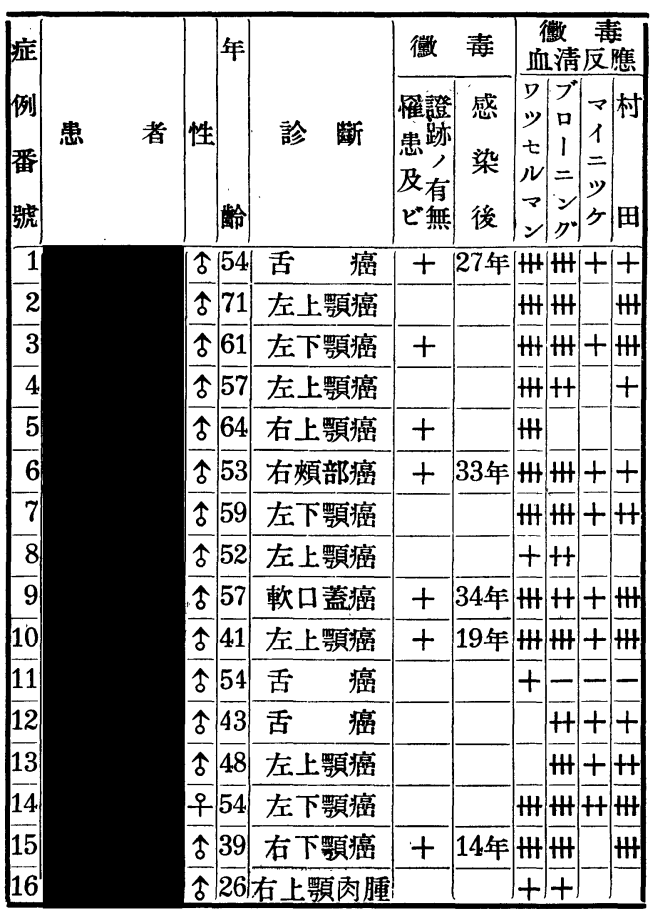

又之レヨ取扱ハレタ 惡性腫場總數二比較（第 2 表）
スルト $22.8 \%$ 占メ且ツ男性八女性二比シテ迤力二 發生率ノ多1事加認メラレル。性別的二八(第 3 表), 男性 15 女性 1 デ $93.6 \%$ >高率 7 男性二鯰メラレル。

第 2 表

\begin{tabular}{|c|c|c|c|}
\hline 症 例 性 & 男 & 女 & 計 \\
\hline 例 & 47 & 23 & 70 \\
\hline 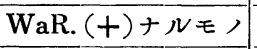 & 15 & 1 & 16 \\
\hline 百 分 & $31.9 \%$ & $4.3 \%$ & $22.8 \%$ \\
\hline
\end{tabular}

第 3 表

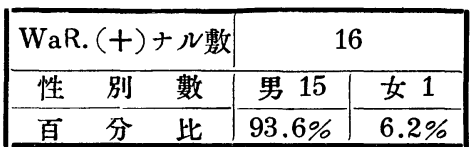

第 4 表

\begin{tabular}{|c|c|c|c|}
\hline 例 數 & 總 數 & $\left|\begin{array}{l}\text { 氐反應 } \\
\text { 陽性ナル } \\
亡 /\end{array}\right|$ & 百 \\
\hline 癌 & 48 & 15 & 31.2 \\
\hline 因 & 22 & 1 & 4.5 \\
\hline
\end{tabular}

徽毒血清反隹，發現率 $\exists$ 病類的二分類シテ見ルト (第 4 表)，16 例中 15 例八癌腫 デ癌腫總數＝對スル百 分比ハ $31.2 \%$ デアッテ肉腫八肉腫總數， $4.5 \%$ 陽性 デアルノヨ認メルニ過ギナイ。

郎千惡性腫瘍中, 徽毒血清反虑, 陽性ナルモノ八 大牛ハ癌腫デアル事が認メラル。

惡性腫瘍ノ「ワ」氏反應陽性率 7 病類及ビ 性別的二 觀察シテ見ルト第 5 表二示ス樈ナ成績デアル。發生部 位別的 =八上顎 7 例, 下靧 4 例, 舌 ，順位デ部位別的 


\begin{tabular}{|c|c|c|c|c|}
\hline 病 & 名 & 男 & 女 & 計 \\
\hline 癌 & 腫 & 32 & 16 & 48 \\
\hline 肉 & 腫 & 15 & 7 & 28 \\
\hline 總 & 數 & 47 & 23 & 70 \\
\hline \multirow{2}{*}{$\begin{array}{l}\text { ワ氏反潐 } \\
\text { 陽 }\end{array}$} & 癌腫 & 14 & 1 & 15 \\
\hline & 肉腫 & 1 & 0 & 1 \\
\hline \multicolumn{2}{|l|}{ 訪 } & 15 & 1 & 16 \\
\hline 百 分 & 比 & $31.9 \%$ & $4.3 \%$ & $22.8 \%$ \\
\hline
\end{tabular}

二總數ニ對シテ，百分比：第 6 表二示ス樣ナ結果卜 ナッテ居ル。

第 6 表

\begin{tabular}{|c|c|c|c|c|c|c|c|c|}
\hline \multicolumn{2}{|c|}{ 病 類 部位別 } & 上顎 & 下頍 & 舌 & $\begin{array}{l}\text { 口腔 } \\
\text { 底 }\end{array}$ & 煩 & 軟口 & 計。 \\
\hline \multicolumn{2}{|c|}{ 癌 } & 21 & 11 & 9 & 3 & 2 & 1 & 47 \\
\hline \multicolumn{2}{|c|}{$\begin{array}{l}\text { ワ氏反隹陽性 } \\
\text { ナルモ， }\end{array}$} & 6 & 4 & 3 & 0 & 1 & 1 & 15 \\
\hline \multicolumn{2}{|c|}{ 肉 } & 15 & 8 & 0 & 0 & 0 & 0 & 23 \\
\hline \multicolumn{2}{|c|}{$\begin{array}{l}\text { ワ氏反篧陽性 } \\
\text { ナルモた }\end{array}$} & 1 & 0 & 0 & 0 & 0 & 0 & 1 \\
\hline \multirow{2}{*}{$\begin{array}{l}\text { 總 } \\
\text { 數 }\end{array}$} & 腫瘍 & 36 & 19 & 9 & 3 & 2 & 1 & 70 \\
\hline & $\begin{array}{l}\text { WaR. }(+) \\
\text { ナルモ, }\end{array}$ & 7 & 4 & 3 & 0 & 1 & 1 & 16 \\
\hline \multicolumn{2}{|c|}{$\begin{array}{l}\text { 總數二對スル } \\
\text { 白分比 }(\%)\end{array}$} & 19.4 & 21 & 33.3 & 0 & 50 & 100 & \\
\hline
\end{tabular}

又發生部位 $\exists$ 性别的二調查シタ結果八何等見ル可 キ樣ナ成績ナク第 6 表ト殆ド同樣ナ 結果 $\exists$ 示シテ居 N。

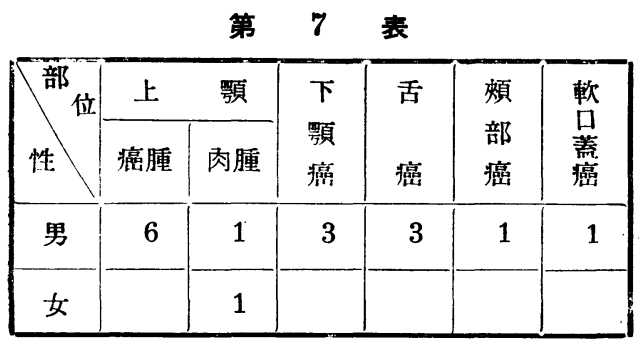

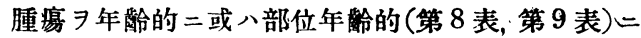
観察シテ見タが特記スル樣ナ事モ無ク本學醫學部齒 科「クリニツク」デ取リ扱ツタロ腔惡性腫癔患者ノ年 龄的發生頻度, 統計曲線卜同一成績 $コ$ 示シテ居ル。 師チ 50-60歳が好發年龄ト云ッテモ差支エナカ口ウ 卜思フ。

\section{第 8 表}

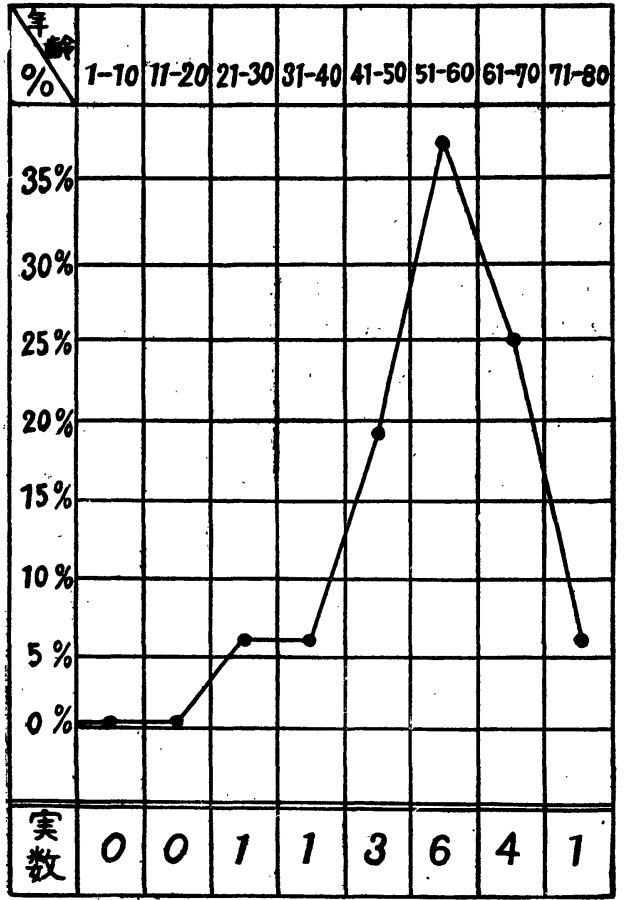

\begin{tabular}{|c|c|c|c|c|c|c|c|}
\hline 部 位 & & 顎 & 下 & 舌 & 煩 & 軟 & \\
\hline 年 龆 & $\begin{array}{l}\text { 癌 } \\
\text { 腫 }\end{array}$ & $\begin{array}{l}\text { 闪 } \\
\text { 腫 }\end{array}$ & $\begin{array}{l}\text { 䫑 } \\
\text { 癌 }\end{array}$ & 癌 & $\begin{array}{l}\text { 部 } \\
\text { 癌 }\end{array}$ & $\begin{array}{l}\text { 蓋 } \\
\text { 癌 }\end{array}$ & 計 \\
\hline $1-10$ & & & & & & & 0 \\
\hline $11-20$ & & & & & & & 0 \\
\hline $21-30$ & & 1 & & & & & 1 \\
\hline $31-40$ & & & 1 & & & & 1 \\
\hline $41-50$ & 2 & & & 1 & & & 3 \\
\hline $51-60$ & 2 & & 1 & 1 & 1 & 1 & 6 \\
\hline $61-70$ & 1 & & 2 & 1 & & & 4 \\
\hline $71-80$ & 1 & & & & & & 1 \\
\hline 計 & & 7 & 4 & 3 & 1 & 1 & 16 \\
\hline
\end{tabular}




\section{第 10 表}

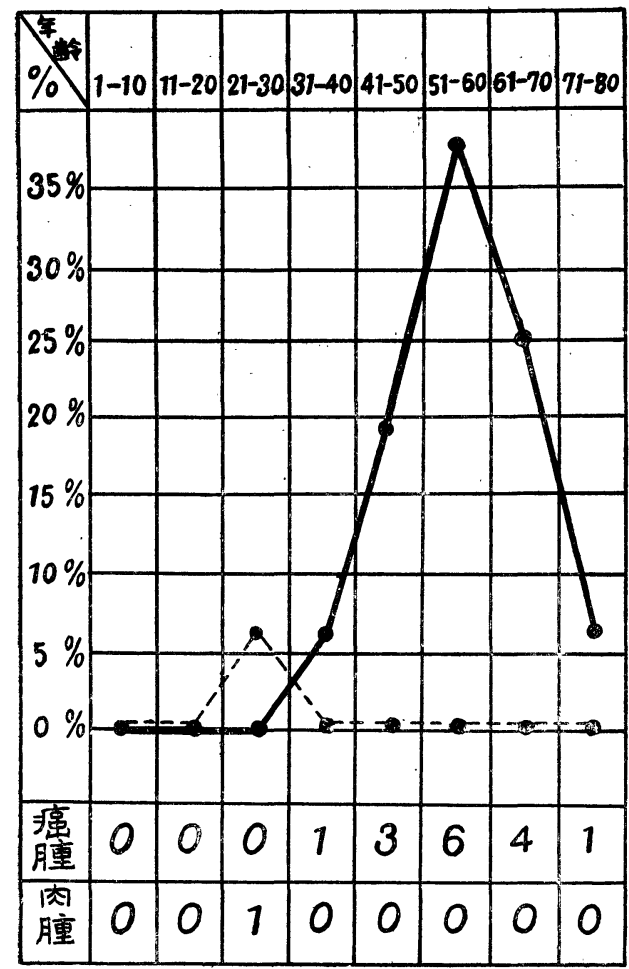

第 11 表

\begin{tabular}{|c|c|c|c|c|c|c|c|c|c|c|c|c|}
\hline$\%$ & 1 & 2 & 3 & 4 & 5 & 6 & 7 & 8 & 9 & 10 & 11 & 12 \\
\hline $30 \%$ & & & & & & & & & & & & \\
\hline $25 \%$ & & & & & & & & & & & & \\
\hline $20 \%$ & & $\Lambda$ & & & & & & & & & & \\
\hline $15 \%$ & & & & & & & & & & & & \\
\hline $10 \%$ & 1 & & & & & 8 & & 5 & $a$ & & & L \\
\hline $5 \%$ & 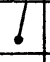 & & & 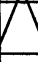 & & & & & & 9 & & 7 \\
\hline $0 \%$ & & & V & & V & & Q & & & & $V$ & \\
\hline 実数 & 1 & 4 & 0 & 2 & 0 & 2 & 0 & 2 & 2 & 1 & 0 & 2 \\
\hline
\end{tabular}

16 症例 病類的二分類シ之レ・年齢的ニ考察シテ 見ル二肉腫二於デ 八比較的青年期二發生シ癌腫二於 テハ老年期が密集的デアッテ且ッ一般惡性腫痬ノ場 合二於ケルト同樣ナ結果 $コ$ 得テ居ル。

季節卜ノ關係二就テハ大ナル意味が無イト考エテ 差支へがナカロウシ又余ノ調查シタ第 11 表八需診期 日ヨ標準トシタモノデアルカラ嚴密ナ意味カラ云へ バ不充分極マリ無ク，從ッテ腫瘍，發生卜季節二關入 ル正確ナル數值ヨ求メラレナイが本表ノ曲線二於テ ハ2月二最高頻度ヨ有シテ居ル。

腫瘍ノ初發症狀二就テハ云フマデモナク口腔ノ一 般惡性腫瘍二於ケルト同樣二, 靧癌二於イテハ齒痛乃

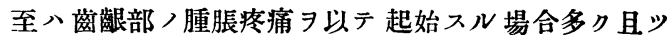

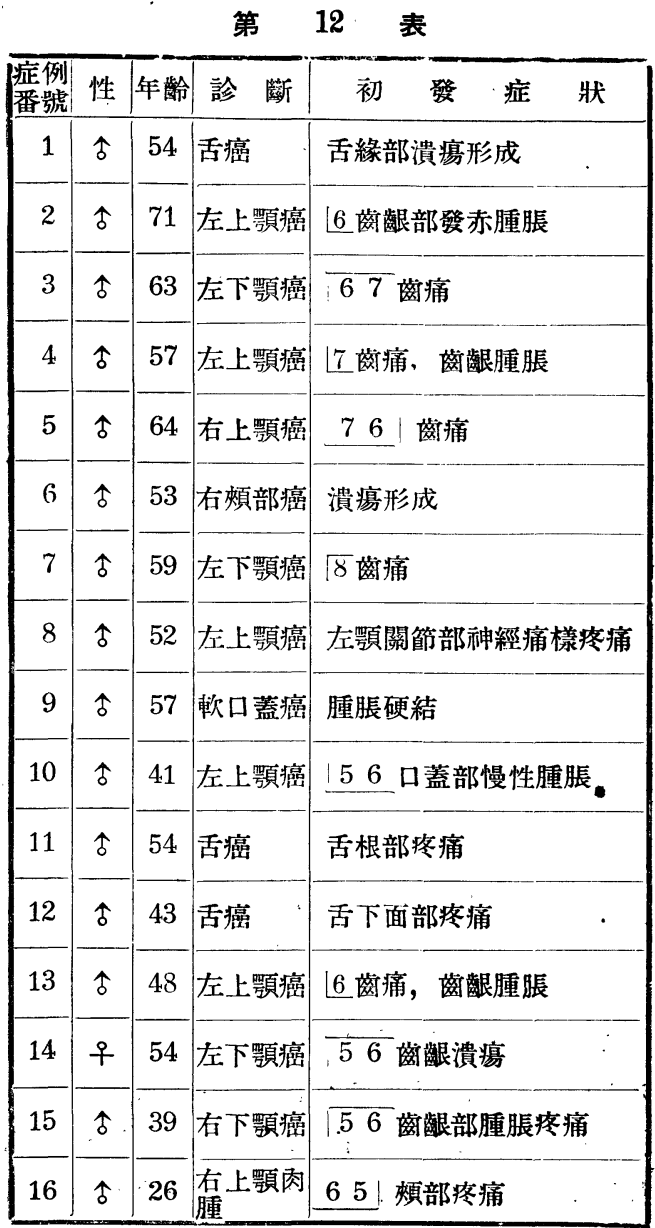


まトシテ舊萃部二限局サレテ居ルノヨ認メル。舌癌

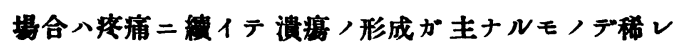

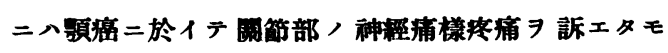
ノモアル(第 12 表)。

\section{泺 13 意}

\begin{tabular}{|c|c|c|c|c|c|c|c|c|c|c|c|c|c|c|}
\hline \multirow{3}{*}{$\begin{array}{l}\text { 症 } \\
\text { 例 } \\
\text { 番 } \\
\text { 號 }\end{array}$} & \multirow[b]{3}{*}{ 性 } & \multirow{3}{*}{$\begin{array}{l}\text { 年 } \\
\\
\\
\text { 跲 }\end{array}$} & \multirow{3}{*}{$\begin{array}{l}\text { 赤 } \\
\text { 血 } \\
\text { 球 } \\
\text { 沈 } \\
\text { 降秏 } \\
\text { 速單 } \\
\text { 度位 }\end{array}$} & \multirow{3}{*}{$\begin{array}{l}\text { 血 } \\
\text { 色 } \\
\text { ! } \\
\text { ! } \\
\text { 素 }\end{array}$} & \multirow{3}{*}{$\begin{array}{l}\text { 赤 } \\
\text { 血 } \\
\text { 球 } \\
\text { 萬 } \\
\text { 總單 } \\
\text { 數位 }\end{array}$} & \multirow{3}{*}{$\begin{array}{l}\text { 白 } \\
\text { 血 } \\
\text { 球 } \\
\text { 楼 } \\
\text { 數 }\end{array}$} & \multicolumn{8}{|c|}{ 白血球百分比率(Schilling 氏法) } \\
\hline & & & & & & & \multirow[b]{2}{*}{$\begin{array}{l}\text { 㽪 } \\
\text { 基 } \\
\text { 性 } \\
\text { 細 } \\
\text { 胞 }\end{array}$} & \multirow[b]{2}{*}{ 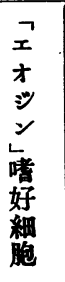 } & \multicolumn{4}{|c|}{ 中性唶好細胞 } & \multirow[b]{2}{*}{$\begin{array}{l}\text { 淋 } \\
\text { 巴 } \\
\text { 細 } \\
\text { 胞 }\end{array}$} & \multirow[b]{2}{*}{$\begin{array}{l}\text { 犬 } \\
\text { 單 } \\
\text { 核 } \\
\text { 細 } \\
\text { 胞 }\end{array}$} \\
\hline & & & & & & & & & $\begin{array}{l}\text { 骨 } \\
\text { 籍 } \\
\text { 型 }\end{array}$ & $\begin{array}{l}\text { 幼 } \\
\text { 若 } \\
\text { 型 }\end{array}$ & $\begin{array}{l}\text { 桿 } \\
\text { 狀 } \\
\text { 型 }\end{array}$ & $\begin{array}{l}\text { 分 } \\
\text { 葉 } \\
\text { 型 }\end{array}$ & & \\
\hline 1 & $\hat{\delta}$ & 54 & & 79 & 459 & 8200 & 0 & 0 & 0 & 0 & 24 & 38 & 25.3 & 10.7 \\
\hline 2 & $\hat{\delta}$ & 71 & & 60 & 331 & 11700 & 0.35 & 2.5 & 0 & 0 & 23 & 39.3 & 12.5 & 22 \\
\hline 3 & $\hat{\delta}$ & 63 & 45 & 50 & 358 & 4800 & 1 & 1 & 0 . & 22 & 0 & 51 & 19 & 5 \\
\hline 4 & $\hat{\delta}$ & 57 & & 75 & 422 & 11700 & 0 & 3 & 0 & 0 & 8 & 66 & 16 & 7 \\
\hline 5 & $\hat{\beta}$ & 64 & & 67 & 318 & 6400 & 0 & 0 & 0 & 28.5 & 0 & 31 & 30.5 & 11 \\
\hline 6 & $\hat{\delta}$ & 53 & 40.5 & 73 & 396 & 13500 & 0.5 & 1.5 & 0 & 1 & 4 & 71 & 13 & 9 \\
\hline 7 & $\hat{\delta}$ & 59 & & 81 & 412 & 6600 & & & & & & & & \\
\hline 8 & $\hat{\delta}$ & 52 & & 85 & 390 & 7800 & & & & & & & & \\
\hline 9 & $\hat{\delta}$ & 57 & 2 & 95 & 465 & 10300 & 2 & 0 & 0 & 0 & 9.5 & 39.5 & 43 & 6 \\
\hline 10 & $\hat{\boldsymbol{\beta}}$ & 41 & 39 & 61 & 302 & 4200 & 0 & 2 & 0 & 0 & 18 & 56 & 24 & 0 \\
\hline 11 & $\hat{\delta}$ & 54 & 6 & 80 & 366 & 5600 & 0.5 & 0.5 & 0 & 0 & 4 & 53 & 37 & 5 \\
\hline 12 & $\hat{\delta}$ & 43 & 33 & 100 & 430 & 9400 & 0 & 0 & 0 & 4 & 3.5 & 53.5 & 29.5 & 9.5 \\
\hline 13 & $\hat{\delta}$ & 48 & & & & & & & & & & & & \\
\hline$\bullet 14$ & 우 & 54 & 24 & 91 & 465 & 5900 & 0 & 1 & 0 & 0 & 4.5 & 67 & 22 & 5.5 \\
\hline 15 & $\hat{\delta}$ & 39 & & 75 & 448 & 5600 & 0.5 & 4 & 0 & 0 & 6 & 62 & 21.5 & 1.5 \\
\hline 16 & $\hat{\delta}$ & 26 & & 80 & 468 & 11200 & & & & & & & & \\
\hline
\end{tabular}

血浓所見ハ大同小異デ特ニ注目ス可キ椂ナ事柄モ ナイ樣二思フ。即千其八平均㑯八赤血球沈降反應 (Westergren 氏法) 27 粍; 血色素(Sahli 氏法) 76\%， 赤血球 402 萬，白血球 8190 ／成績デー般， 口腔惡性
腫湯時ト比較シテ大差ナイモノト考ェラレル（第 13 表)。又是等 /腫瘍患者二随件シテ來ル諸症狀ト云ッ テモ特異型 /症狀ハ認メラレナイト論ジテモ過言デ 無カロウト思つ(第 14 表)。 


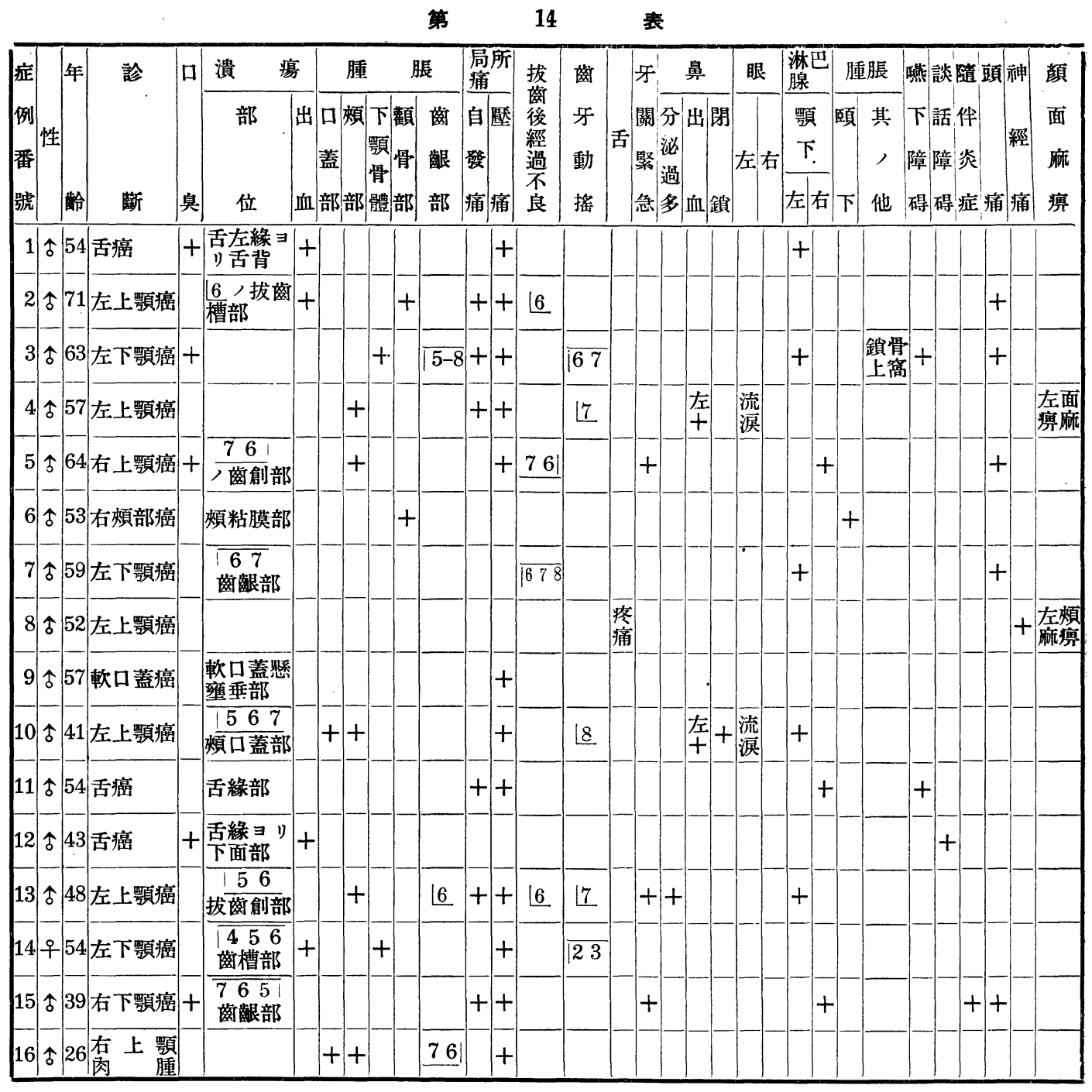

\section{第3章考按}

輓近, 實驗腫瘍學ノ進步ニョッテ惡性腫瘍卜 炎症特二慢性炎症卜ハ全ク不可分, 關係二在ル 事ハ一般的證左チ得ル樣ニナッタ。ソシテ慢性 炎症丹起入所ノ疾病ノ一ツト考エラレテ居ル徽 毒卜ノ關係二就テハ從來ヨリ種々ナ報告ガアッ テ徽毒ノ各期ノ病變カラ惡性腫瘍ノ發生キ見ル 場合ガ多イトサレテ居ル。

Fournier (1900 年) 八口腔內癌腫, 184 例中 155 例二其, 既往症二徽毒き發見シタト云ヒ,
Hutchinson (1903 年) 八第吕期徽毒ヨリ發生シ タ舌上皮腫及ビ口腔癌, $30 \%$ 徽毒性原因 認メテ居ル。Etcheverry (1904 年) ハ三ッ，條 件チ示シテ居ル。郎チ惡性腫瘍ハ口腔白斑ョリ 發生シ, 徽毒八惡液質, 原因的素質チ作リ, ソシ テ口腔粘膜癌八徽毒性疾患チ基礎トシテ發生大 ルト記載シテ居ル。Montogomery and Shermann (1907 年) 八舌)徽毒性潰瘍ヨリ發生シタ 上皮腫, Horrand 八徽毒性白斑ヨリ癌腫八發 


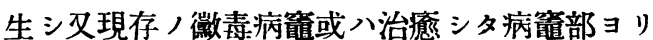
發生シ、一方癌二對シテ一般的前素因ナナシ殊 二舌癌患者二於テ八兩親兩租父母， $85 \%$ 二於 テ徽毒タ證明シ其?關係タ强調シテ居ル。然シ Coecnen 八舌癌患者ノ中デ Wassermann 氏反 應ノ陽性ナモノ八自驗例中 1 例モ認メラレナカ ツタト報告シテ居ル。A. und F. Theilhaber (1909 年)八徽毒性潰瘍二ヨル䃝痕八徽毒性白 斑ト同樣二癌腫發生ノ誘因トナル事ガ多イト云 七，Virchow モ又軗痕が重大ナル役割チ有入 ルモノトシテ居ル。Gougerot (1912 年) 102 人, 舌癌患者 $=90 \%$, 徽毒, 合併 二扁平上皮癌ノ場合八屢了白斑キ見ルモモノ゙ァ リ概皂徽毒,產物デアッテ, 癌前駱症デアルト 云ヒ陰部，癌腫二モ同樣ナ゙關係ガアルモノト シテ居ル。

一般癌腫患者卜徽毒卜ノ關係二就テハForester $(1911$ 年) 35 例中 4 例, Cann ハ 85 例中 35 例, Fox (1913 年) 207 例中 5 例/陽性例 于報告 シ, 次デ Mac Coranc u. Morson (1914 年) 137 例ノ惡性腫瘍中 $10.2 \%$ 陽性率方報告 シ, 其 他二八 Stumms, Schenk, Weil u. Braun, Fränkel 等ノ報告ガ有ル。Frey ハ1000例ノ癌 腫患者ノ「ワ」氏反應ノ成績ヨリ見テ徽毒八癌腫 發生二重要ナル關係ナシト云ッテ居リ v. Berg$\operatorname{mann}(1883$ 年) モ同樣特殊, 原因的意義于有シ テ居ナイトシテ居ル。

本邦デハ今野, 戶部氏，121 例中 19 例, 關口 氏，47 例中 3 例，陽性例數テ報告シテ居ル。 Ledermann (1913 年) 八喉頭, 舌ノ癌腫患者 擧ゲテ徽毒八癌發生二局所的ナ素因チ作ル。ソ シテ其/重大且ツ著明ナモノ八白斑デアルトシ テ居ル。Cary 二據ルト 199 例ノ舌癌患者中 29 例, 173 例, 下口甬癌患者中 12 例, 771 例ノ口腙 癌患者中 48 例，陽性數于認メ，34 例ノ上口肩 癌患者中 1 例モ認メナカッタト云七, J. Strandberg 八陰经癌及ビ舌癌チ報ジテ徽毒性潰瘍 ヨリ癌發生キ見ルト論ジテ居ル。

H. Schleicher (1925 年) 八喑癌八主要ナ原因
トシテ慢性炎症，創傷，痈痕等ノ形デ來ル慢性 刺激卜是等ノ狀態于惹起スル白斑, 徽毒, 煙草 , 間接原因丹區別 シ更二是等,刺激ガ共同二作 用スル場合二一層其ノ發生率き增大スルトシテ 居ルガ此等ノ原因中徵毒トノ關係ハ左程重大ナ モノデナイト述べテ居ル。

O. Sachs 及ビ v. Jonesen 等八辞及ビ口埥 八徽毒性白斑ヨリ癌發生き報シ更二 Sachs ハ 口腔粘膜二就キ特殊, 白斑, 護謨腫上二見ラレ タ上皮腫キ報告シテル。

Bablet (1926 年) 八口腔粘膜癌二 於テハ發生 ノ重要因子二次イデ徽毒, 流行地方ガ意義有ル モノトシテ居ルガ是等ノ提言二對シテハ直チニ 贊成出來得ナイト思フ。

Roussy，G. et Berillon(1927 年) 八口腔，咽 頭, 喉頭, 粘膜, 上皮腫 105 例 7 組織的, 臨牀 的二又血清學的二檢索シテ徽毒，因子的關係ハ 左程重大ナモノデハナイトシテ多クノ研究二反 對シテ居ルガ Leitch (1928年) 八舌ノ徽毒性變 化八局所ノ抵抗丹減ジテ癌發生ノ素因キ作ルモ ノトシ Verrotti ハ先人ノ業績及ビ自己，口腔 癌及ビ舌癌丹觀察シテ其ノ關係チ强調 シ Belate モ又辞癌患者， $29.3 \%$ 「ワ」氏反應陽性子認 メタト云七 Goyanes (1932 年) 八口腔癌， 685 例中 44 例八僌毒ガ疑ハシク，35 例ハ「ワ」氏反 應陽性デアッタ・ト云ツテ居ル。

金野氏 (1935 年) 八 臨牀上口蓋護謨腫卜診定 シ組織學的檢查ニョリ扁平上皮癌デアッタ「ワ」 氏反應强陽性丹示シタ 2 例 報告シテ居ル。余 , 症例中 (第 8 例) 二臨牀診斷が護謨腫デアッタ 上顠癌腫例キ經驗シテ居ル。ソシテ金野氏ノ症 例二於テハ骨缺損テ補フタメニ 10 數年「プロテ 一ゼ」キ使.用シ然カモ癌腫八其ノ邊緣二相當シ テ發生シタモノデアル。余ノ症例(第 1 例, 第 2 例，第 14 例) 二於テモ「ブロテーゼ」ノ不適合二 ヨッテ癌腫ノ發生き認メタ。此ノ樣ナ事實八吾 々臨牀家ノ甚ダ興味アル事デアリ又特二注目ス 可キ事柄デアロウト思フ。

A. Merkin 八癌腫ト徽毒トノ關係き論ジロ 
膑及ビ生殖器癌腫二徽毒ヨリ起ル白斑ガ重大ナ ル意義ガアルト述べテ居ル。

此, 口腔癌腫卜白斑, 白斑, 發生卜徽毒卜, 關係二就テハ贊否兩樣デアルガ白斑ヨリ癌腫二 轉化シ來ル場合キ認ムルモノハ Schuchardt, Nedopil, Bergmann 等デァルガ此ノ白斑ガ如 何ナル原因デ告起サレルカト云フ二古クヨリ過 度ノ喫煙者二見ラル、トサレテ居ルガ, 一方特 發的二發生スルモノト考へラレテ居ツタガ其, 後本症ガ徽毒二關係アルモノト見ラレテSchöngarth, Schaffer, Guszmann, Coenen, /臨牀 的證明ガ有ッテ此等, 論旨二對シテ v. Bergmann, Genschner, Kopp, Janavsky, Bockhart, Bleer 等ハ之レテ承認 シ, 現在一般ノ䞶勢八白 斑ノ發生二徽毒八重要ナル因子ノ一ツト考へラ レテ居ル。

余ノ症例二於テ八此ノ樣ナ事柄八認メラレナ カツタガ舌癌例（第 1 例第 12 例）デ八舌徽毒症

\section{第 4 章 結 論}

1. 口膑, 惡性腫瘍 70 例中 Wassermann 氏反應陽性ナルモノ 16 例 $(22.8 \%)$ デ內男 15 例 女 1 例デアル。

2. 16 症例中癌腫 15 例肉腫 1 例デ 徽毒罹患 後腫瘍發生マデノ經過ノ明カナモ，5例ノ本均 經過日數ハ 25,4 年デアル。

3. 發生部位的二八上顎二最モ多ク下顎, 舌 之レニ次ギ，年龄的二八特異ナル關係八認メラ レナイ。

\section{文}

1）金野，診溦卜治療. 第 22 卷. 第 7 號.

2）內藤， 日本婦人科學雜誌. 第 32 卷. 8 號.

3) 都築, 皮膚科泌尿器科雜誌. 第 33 卷. 4 號.

4) 中田，實驗醫報. 第 21 年. 第 246 號.

5）赤岩, 實地䝷家卜臨牀. 昭和 6 年 4 月.

6) 山上, 口腔病學會雜誌. 昭和 5 年 3 月.

7) 田岡, 産婦人科紀要. 第 19 卷. 10,11 號. 20 卷. 1 號.

8) 小林, 中野, 大日本兴科醫學會會誌. 74 卷.
ト診斷サレラ驅徽療法キ行ナッタモノガアル。 其ノ他當初顎炎卜診定サレタガ精查ノ結果下顎 癌腫(第 15 例) デァッタ症例モ經驗シテ居ル。

以上述べタ樣ナ諸家ノ意見チ綜合シテ見ルト 徽毒, 各期ノ病變ヨリ癌發生キ見儿場合多ク, ソシテ此,兩者, 關係八局所的二八其ノ局所病 變ニヨル慢性刺激卜局所ノ'組織本衝ノ失調ニヨ ルモノト考へラレ又全身的ニ八何等カノ影響ア ルモ,ト認メラレテ居ル。

此, 徵毒卜惡性腫瘍,發育二就イテノ實驗的 研究八臨牀的成績二比較シテ稍了箃莫ノ感ガア ルケレ共田岡氏ハ實驗徽毒ノ惡性腫瘍二及ボス 影響ノ一ッ八徽毒ニヨッテ網狀織內被細胞系統 ノ機能,變調ニョルト發表シテ居リ，岩下氏モ 又同樣ナ實驗キ系統的ニ行ナッテ報告シテ居ル ガ是等兩者ノ關係二就テハ究明サレル可キ點ガ 未ダ殘サレテ居ルモノト思つ。

4. 16 症例中顎腫瘍ハ 10 例デ何レモ齒痛或 八齒龈, 腫瘍又八疼痛テ初發症狀トシテ居儿。

5. 16 症例中義苳, 不適合 ガ腫瘍發生ノ誘 因卜認メラレタモ,ガ 3 例アル。文顎炎或八護 謨腫ノ臨牀診斷き受ケタ症例ガ各々 1 例認メ タ。

終リ二御指導卜御校閲 9 賜 ッタ金森敎授二感謝, 意ヨ表スルモノデアル(昭和 13 年 4 月稿)。

(本稿)要旨 八昭和 11 年日本疅科學會第 2 回分科 總合大會デ講演シタ)。

文獻

2 號.

9）岩下, 皮膚科泌尿器科雜誌. 42 卷. 1 號. 3 號.

10）東大父科，日本之蓄界. 第 203 號. 204 號.

11）吉井，大日本耳鼻咽喉科會會報. 第 1,2 號.

12）森田, 十全會雜誌. 22 卷. 12 號.

13）洞口, 東北醫學雜誌. 15 卷. 3 册.

14）西島. 九大醫報. 第 5 卷. 第 2 號.

15) R. Kronfeld, J. Amer. Dent. Asso. S. 1900, 1931 年. 
16) Belate G. H., Amer. J. Syphilis. Vol. 15. S. 372 .

17) Etcheverry; Arch. f. Dermat. Bd. 75. S. 132.

18) Gougerot, Arch, f. Dermat. Bd. 115.

19) Lambert, Ztschr. Haut u. Geschl. Bd. 5. S. 159.

20) Martin, Joseph F. et A. Colrat, Ztschr. Haut u. Geschl. Bd. 4. S. 71.

21) Roussy, G. et Berillon, Ztschr. Haut u. Geschl. Bd. 27. S. 795.

22) Sachs, Otto, Wien. med. Wschr. Gg. 75. Nr. 9. S. 527.

23) Strandberg. J., Zbl. Haut u. Geschl. Bd. 4. S. 181.
24) Wellmann, E., Dermat. Wschr. Bd. 77. Nr. 45. u. 46 .

25) Goyanes, Zbl. Haut u. Geschl. Bd. 39. S. 95.

26) A. Tourainer and C. Ribadeau-Dumes, Amer. J. Canc. Vol. 18. p. 158.

27) Fournier, Z. Krebsforschg. Bd. 6. S. 477.

28) Belate. G. H., Z. Krebsforschg. Bd.33.S. 31.

29) Horand, Z. Krebsforschg. Bd. 6. S. 484.

30) H. Schleicher, Z. Krebsforschg. Bd. 22.

31) A Theilhaber u. F. Theilhaber, Z. Krebsforschg. Bd. 9. S. 555.

32) Ledermann P., Z. Krebsforschg. Bd. 13. S. 579.

33) Verrotti, Z. Krebsforschg. Bd. 33. S. 51.

\title{
兩側顎下腺二發生セル稀有ナル唾石症ニ就テ
}

\author{
滿洲䃜科大學齒科
}

醫學博士 中 村 議 兵 衞

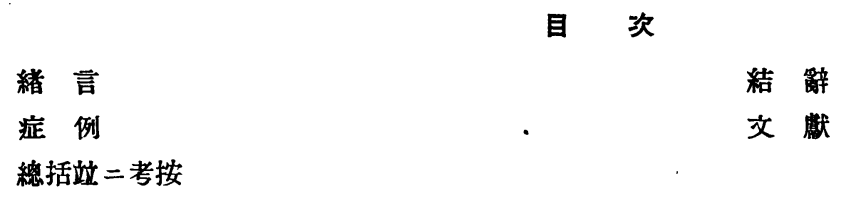

生體ニ於ヶル結石形成ノ成因二關シテハ幾多 ノ業績アリ。唾液腺ノ結石形成二關シテモ, 近 時多數ノ報告アリ。臨牀的二, 實驗的二, 或八 綜說的記述七ルモノアリテ全貌テ明ニセル感ア ルモ，佾未ダ唾石形成ノ成因二關シテハ不明ノ 點多シ。唾液腺ノ結石形成八直二其ノ機能障碍 チ意起スルモノニアラズ。數年ニ涉リテ何等障 碍キ來スコトナク過グルコトアリ。サレド一面 小ナル結石ニヨリテモ癌腫キ形成セル (赤坂) 如 キ危險性キ有スルモノアリ。攵殊二 Deseoendres ノ報告セル如ク唾石ノ存在ノ結果少量ナ
ル膿汁ノ持續的唯下トナリ 12 年間モ・胃潰瘍ノ 治瘾スルコトナカリシニ器石摘出ニヨリ胃症狀 八盡ク消散セリト稱入。斯ノ如ク唾石ノ大小, 數ニヨルコトナク筒體, 素質, 狀況泣二位置二 ヨルモノナラン。

唾石ノ形成八一般二一側ノ唾液腺二形成七ラ ル、モノニシテ兩側共二結石成形チ見ル八非常 二稀ナリ。余八兩額下腺二發生七儿唾石 /症例 チ得タルチ以テ此處二報告シ聊カ從來ノ文獻二 補遺スル所アラントス。

症例 